高強度鉄筋用グラウト充媜式鉄筋継手を持つ PCa 柱部材の挙動と 耐力評価に関する研究

\title{
RESEARCH ON THE MECHANICAL BEHAVIOR AND FLEXURAL STRENGTH OF PRECAST CONCRETE COLUMNS USING HIGH STRENGTH GROUT-FILLED COUPLING SLEEVES
}

\author{
新藤 健 太*, 槙 谷栄 次**, 小曾根 茂雄***, 礒 健一**** \\ Kenta SHINDO, Eiji MAKITANI, Shigeo OZONE \\ and Ken-ichi ISO
}

\begin{abstract}
In the present study, we conducted out the flexural test of column corresponding to the first story in tigh rise frame consisted of precast concrete syructure, in order to investigate the mechanical behaviors under seismic load.

This paper aims at evaluating the ultimate flexural capacity of a precast concrete column connected by grout-filled coupling sleeves for the steel bar with high strength. By using the theory of compressive struts constituted in precast concrete column, the model on tie action and arch action is conducted and its conformity to experimental results is verified.
\end{abstract}

\section{Keywords : High strength materials, Grout-filled coupling sleeves, Precast concrete columm, Ultimate flexual strength, Compressive strut \\ 高強度材料, グラウト充填式鉄筋継手, プレキャストコンクリート柱, 曲げ終局強度, 圧縮ストラット}

1.はじめに

近年, 工期の短縮や，作業環境の改善，地球環境への配慮等の社 会的背景から，鉄筋コンクリート構造物のプレキャスト(以下PCa と略す)化が進んでいる。また高強度鉄筋およびコンクリートを用 いた高層RC造建築物は，SRC造に比して建設コストの削減が期待 できるため，需要が急速に高まっている。PCa鉄筋コンクリート構 造では，鉄筋の継手が重要な要素であり，高首RC造で用いられる 高強度鉄筋を継ぐための継手の開発が急務となっててる。このうち グラウト充填式鉄筋継手は溶接や重ね継手と異なり，接合部の後打 コンクリートが不要で, 鉄筋位置などの施工誤差をある程度吸収で きるだけのクリアランスを持っており，太径鉄筋にも対応できるこ とから，近年急速に普及している(1)。

グラウト充填式鉄筋継手を持つPCa部材の力学的挙動については これまでも数多く報告されている。しかしながら，高強度鉄筋，高 強度コンクリートを用いた，グラウト充填式鉄筋継手を持つPCa部 材の研究について報告された例は非常に少ない。既往の研究成果で は，PCa部材に高強度コンクリートを用いた場合の強度増分が，実 際の曲げ挙動にどのような影響を与えるか，十分に検討されたとは 言えないのが現状である。また高強度材料を使用した，柱部材の曲 げ終局強度の評価についても, New RC の報告はあるものの, 下限
値で評価しているため, 高強度部材の耐力を適切に評価できるとは 言い難い。また従来のいわゆるFiber Model についても, 特にコン クリート強度が高強度の場合, 圧縮領域におけるコンクリート圧縮 強度の寄与について不明確な点が多い。

本研究は，SD490鉄筋の接合に用いられるグラウト充填式鉄筋継 手を脚部に持ち、 $\mathrm{F} c=60(\mathrm{MPa})$ クシスの高強度コンクリートを使用 したPCa柱部材の力学的特性を調べるため, 継手の有無や軸力比等 を変動要因として，曲け破壊実験を行った。これより，高強度材料 の適用性に関し，柱脚に剛性の大きい継手が配された場合の曲げ強 度に与える影響や，高軸力の影響等について実験結身より検証した。 また柱部材のコンクリート強度を高強度にした場含，曲げ終局耐 力は上昇することが報告されている。これは高強度こンクリートを 使用した場合，柱脚の圧縮領域に余裕度が生じ，曲佀耐力に奇与し ているものと考えられる。本研究では，従来の普通強度を対象とし たモデルでは対応しきれなかった，高強度材料を用いたPCa柱部材 の曲げ終局強度を評価するため，任縮ストラットータイモデルおよ びアーチモデルによって曲げ終局強度を導き，その適合性に関して， 実験結果ならびにこれまで報告された事例との検証を試みた。以下 にその成果を報告する。

\footnotetext{
*ベターリビング筑波建築試験センター 関東学院大学工学部建築学科 大学院生. 工修

** 関東学院大学工学部建築学科 教授 · 工博

*** 東京鉄鋼技術開発センター

**** 日本国土開発技術開発研究所工修
}

Tsukuba Building Test Laboratory, The Center for Better Living, Graduate School, Dept. of Architecture, Faculty of Eng., Kanto Gakuin Univ., M. Eng.

Prof., Dept. of Architecture, Faculty of Eng., Kanto Gakuin Univ., Dr. Eng.

Technical Department Section, Tokyo Tekko Co., Ltd. 


\section{2. 実験概要}

\section{1 試験体}

本研究に用いた試験体の諸元を表1に示す。試験体はPCa試験体5 体，従来型一体打試験体(以下RC試験体と略す)1体の計6体とした。 試験体断面は幅 $(\mathrm{b}) \times$ 成 $(\mathrm{D})=45 \times 45(\mathrm{~cm})$, 加力点高さ $\mathrm{Hs}=120(\mathrm{~cm})$ で，片持加力方式である。コンクリート圧縮強度の設定目標は

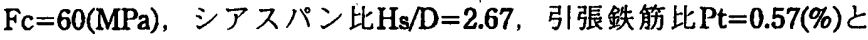
した。変動要因としては，継手の有無，軸方向応力度係数(以下軸 力比と略す), 継手部せん断補強筋位置，かぶり厚とした。PCa試 験体の配筋を図1に示す。

鉄筋継手は，SD490用の両端グラウト充填式スリーブ継手を使用 した。打設は柱部，基礎スタブ部とも横打にて行い，金属型枠面同 土を特に目荒らし等の処理は行わずに接合した。接合モルタル厚は $10 \mathrm{~mm}$ で，従来の敷モルタルは使用せず，継手内のグラウトを継手 下端より流入させ，一体化する全充填一括グラウト方式とした。

\section{2 加力方法・測定方法}

加力は片持形式とし，図2に示すように，オイルジャッキによう て水平力と軸方向力を同時に加えた。オイルジャッキの試験体への 取付に際しては，加力位置に設置したシース管にPC鋼棒を㨂入し て加力治具と緊結し，大変形時においても加力点が移動しないよう にした。オイルジャッキの自重については高軸力下では無視できる ため, カウンターウェイト等は設けていない。

加カサイクルは図3に示すように，変位制御による正負交番繰り 返し載荷とした。引張側鈶直筋が，材料試験による降伏ひずみに達 した時の加力点での変位を $\delta \mathrm{y}$ とし，それぞれ $2,4,6,8$ 倍の変位を 順次載荷した。軸方向力は表1に示すように，コンクリート圧縮強 度の設定目祭 $\mathrm{Fc}=60(\mathrm{MPa})$ に基く軸力比による一定軸力を載荷した。

測定方法は，高感度変位計を設置し，試験体各部の相対変位を測 定した。鈶直接合筋のひずみは塑性域ワイヤーストレインゲージに よって測定した。ひび割れ発生状況は，目視により観測した。

\section{3. 実験結果および考察}

\section{1 材料性状}

試験体に用いた鉄筋の機械的性質を表 2 ，コンクリート材料性 状を表3にそれぞれ示す。鈶直接合筋(主筋)にはSD490を，帯筋には SD785を使用した。実験時のコンクリート圧縮強度 $\sigma$ 流，それぞ れ71.4〜76.8(MPa)となり，設定目䌘をやや上回った。

また本試験体に用いたグラウト充填式鉄筋継手の断面形状を写真 1に示す。写真右が柱脚側，左が柱頭側である。写真は，実験終了 後に柱部材内の引張側鈶直接合筋に配された継手を取り出し，長手 方向に切断したものである。部材角1/17radの大変形後の継手であ るが，拔け出し等は認められず，緊結状態は良好であった。

\section{2 破壊性状}

試験体の最終破壊性状を写真 2 に示す。軸力比 0.2 のCa試験体で は，おおむね $400 \mathrm{kN}$ 近傍で試験体脚部に曲げ初ひび割れが認められ， 順次柱脚から離れた位㯰(上部)に曲げひび割れが発生した。発生し た曲げひび割れは，引張側主筋の位置付近から圧縮側柱脚に向かう
表1 試験体構造踷元

\begin{tabular}{|c|c|c|c|c|c|c|}
\hline 試験体名 & $\begin{array}{c}\text { 継手の } \\
\text { 有無 }\end{array}$ & $\begin{array}{c}\text { 接合モル } \\
\text { タル厚 } \\
(\mathrm{mm})\end{array}$ & $\begin{array}{c}\text { 軸力比 } \\
*_{1}\end{array}$ & $\begin{array}{c}\text { せん断捕 } \\
\text { 强筋配筋 } \\
{ }^{2} 2 \\
\end{array}$ & $\begin{array}{c}\text { 維手部 } \\
\text { かぶり厚 } \\
(\mathrm{mm})\end{array}$ & 珰考 \\
\hline$R C N-01 H$ & $\div$ & - & 0.2 & 一般 & $\div$ & 一体打 \\
\hline$P C-02 H$ & 0 & \multirow{5}{*}{10} & 0 & \multirow{3}{*}{ 一般 } & \multirow{2}{*}{15} & $P C a$ \\
\hline$P C N-03 H$ & 0 & & \multirow{3}{*}{0.2} & & & $P C a$ \\
\hline$P C N-04 H$ & 0 & & & & 30 & $P C a$ \\
\hline$P C N-05 H$ & 0 & & & 端部集中 & \multirow{2}{*}{15} & $P C a$ \\
\hline$P C N-06 H$ & 0 & & 0.4 & 一般 & & $P C a$ \\
\hline
\end{tabular}

幅 $\times$ 成: $(b) \times(D)=450 \times 450(\mathrm{~mm}) \quad$ 引張鉄筋比: $P t=0.57(\%)$ 加力点高さ: $H=1200(\mathrm{~mm})$ せん断補強筋比 シアスパシ比 : $H / D=2.67 \quad$ (一般部)：Pw=1.41(\%) コンクリート強度 : FC=600( $\left.\mathrm{kg} / \mathrm{cm}^{2}\right) \quad$ (継手部) : $P w j=2.26(\%)$ ${ }^{*} 1$ 軸力比 $N /(b \cdot D \cdot F c)$ 継手部のせん断補強筋位置, 配筋図参照
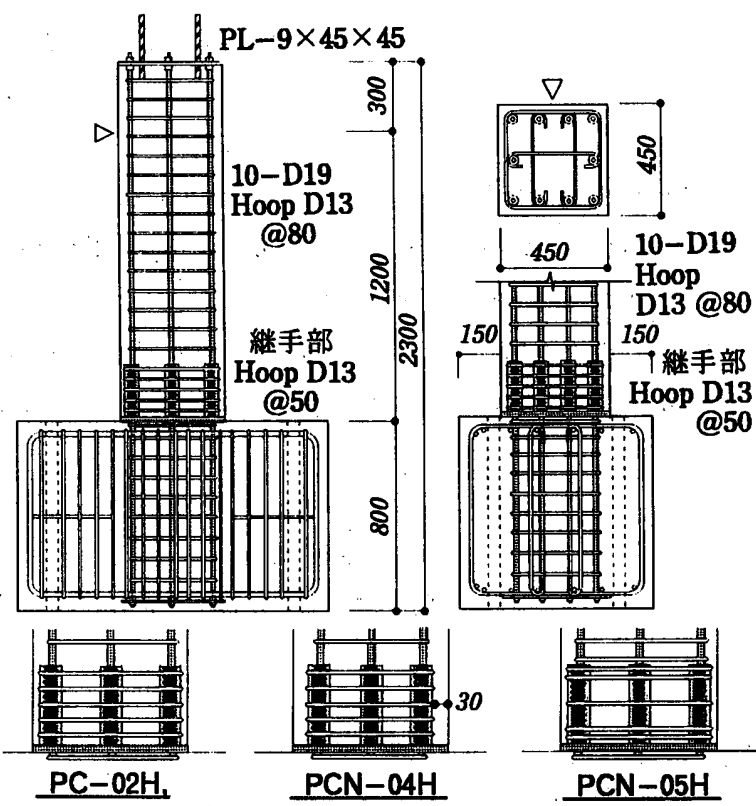

$\mathrm{PCN}-03 \mathrm{H}, 06 \mathrm{H}$ 図1 試験体汇筋

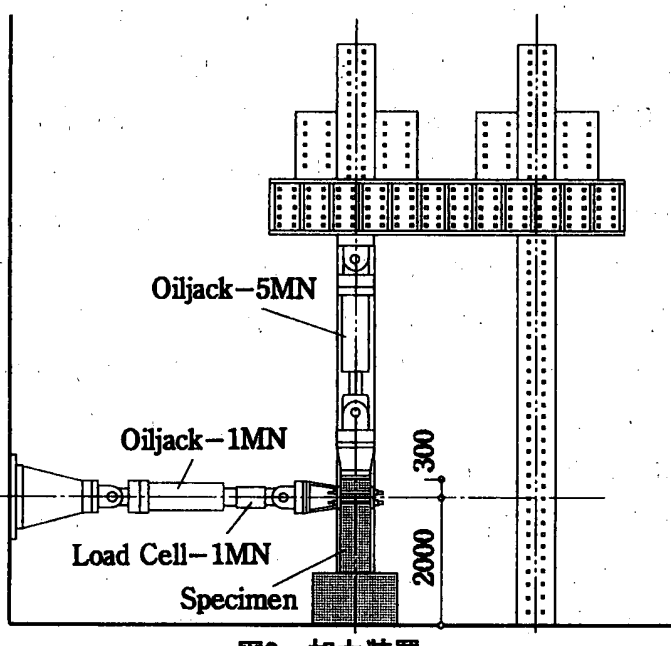

図2 加力装置

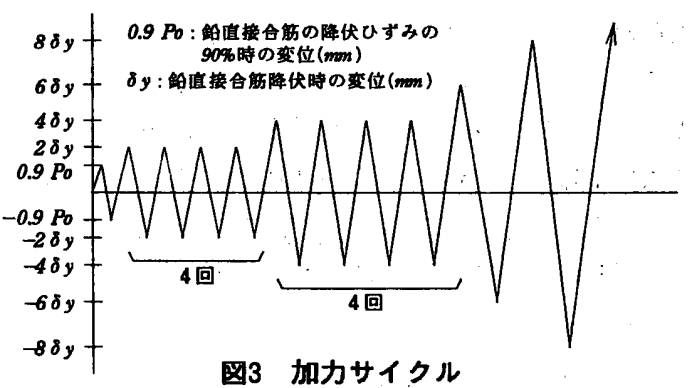

図3 加カサイクル 
てせん断ひび割れに移行する様子が観測された。

軸力のない試験体PC-02Hを除き，脚部の圧壊が進行した。特に 軸力比の高い試験体 $\mathrm{PCN}-06 \mathrm{H}$, 継手のないRC試験体 $\mathrm{RCN}-01 \mathrm{H} て ゙$, 柱脚が大きく圧壊した。これは柱脚に剛性の高い継手を配したPCa 試験体に比べ, RCN-01H試験体の場合脚部に継手のような大きな 抵抗要素がなく，ほとんどの圧縮力をコンクリートのみで負担して いるため, 大きく圧壊したものと考えられる。また压縮側において， 主筋に治った鈶直方向のひび割れの進展が認められた。

載荷終了後の最終破壊性状において, 継手頂部付近のかぶりコン クリートが最も外側に押し出されている傾向が観察された。特に継 手部かぶり厚を $30 \mathrm{~mm}$ 確保した試験体 $\mathrm{PCN}-04 \mathrm{H}$, 軸力比の高い 試験体PCN-06Hに顕著に現れた。これは接合界面から柱成(約1D) だけ上部の引張領域に向かって，圧縮側柱底面より約 $45^{\circ}$ の角度で 押し上げる力が働いたものと推測される(2)。また実験後に， PCa接合面近傍を調べたところ，PCN-05H試験体の引張側鈶 直接合筋1本が，継手直下で破断していることが確認された。

\section{3 諸強度まよひ荷重一変形履歴曲線}

実験から得られた諸強度の一覧を表4に示す。軸力のない試

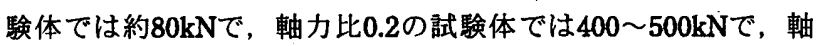
力比 0.4 の試験体では約 $700 \mathrm{kN}$ でそれぞ执曲げ初ひび割れが発生 した。引張側主筋の降伏荷重に大きな差は見られなかったもの の， $\mathrm{RC}$ 試験体に比して $\mathrm{PCa}$ 試験体 の方が，若干大きく発現した。これ は剛性の大きい継手が柱脚に配され たためであると考えられる。

最大耐力については, RC試験体 に比して PCa棐準型試験体 PCN03Hで約 7\%の上昇が認められた(正 側)。また軸力比の上昇に伴って, 最大耐力も上昇することが確認され た。PCN-03H試験体に比して，継 手部かぶり厚を $30 \mathrm{~mm}$ 確保した試験 体 $\mathrm{PCN}-04 \mathrm{H}$, 継手端部に帯筋を集 中させた試験体 $\mathrm{PCN}-05 \mathrm{H}$ とも同等 の強度性能を有していることが認め られた。

最大荷重の $85 \%$ まで耐力低下した 時点の部材角を比較すると， RC試 験体に比して PCa棒準型試験体 PCN-03Hは約25\%の伸びが見られ， 他のPCa試験体のいずれもRC試験 体より勒性が向上していることが認 められた。これはPCa試験体に比し て RC試験体の脚部領域では継手の ような大きな抵抗要素を持たないた め, 最大荷重以降の早い段階から圧 壊が始まったことによる影響である
表2 鉄筋の機棫的性質

\begin{tabular}{|c|c|c|c|c|c|c|}
\hline 径 & 位圈 & 種 類 & $\begin{array}{c}\begin{array}{c}\text { 降伏強度 } \\
(\mathrm{MPa})\end{array} \\
\end{array}$ & $\begin{array}{c}\text { 引張強度 } \\
\text { (MPa) }\end{array}$ & $\begin{array}{c}\text { ヤング率 } \\
(\mathrm{GPa})\end{array}$ & $\begin{array}{c}\text { 伸び率 } \\
(\%)\end{array}$ \\
\hline D19 & 主篮 & SD490 & 516.0 & 675.7 & 192 & 9.2 \\
\hline D13 & 带筋 & SD785 & 849.3 & 1045 & 203 & 12.9 \\
\hline
\end{tabular}

表3 コンクリート材料性状

\begin{tabular}{|c|c|c|c|c|c|c|}
\hline \multirow{2}{*}{ 樲験体名 } & \multicolumn{3}{|c|}{ コンクリート } & \multicolumn{3}{|c|}{ グラウト } \\
\hline & $\begin{array}{c}\text { 圧縮強度 } \\
(\mathrm{MPa})\end{array}$ & $\begin{array}{c}\text { 割裂強度 } \\
\text { (MPa) }\end{array}$ & $\begin{array}{c}\text { ヤング率 } \\
\text { (GPa) }\end{array}$ & $\begin{array}{c}\text { 圧樎強度 } \\
(\mathrm{MPa})\end{array}$ & $\begin{array}{c}\text { 割裂強度 } \\
(\mathrm{MPa})\end{array}$ & $\begin{array}{r}\text { ヤング率 } \\
\text { (GPa) }\end{array}$ \\
\hline $\mathrm{RCN}-01 \mathrm{H}$ & 75.4 & 4.78 & 30.2 & - & - & - \\
\hline $\mathrm{PC}-02 \mathrm{H}$ & 74.4 & 4.75 & 29.7 & 63.4 & 3.87 & 38.0 \\
\hline PCN-03H & 76.8 & 4.38 & 31.0 & 78.3 & 4.46 & 43.2 \\
\hline PCN-04H & 74.2 & 6.28 & 30.7 & 68.0 & 3.56 & 29.0 \\
\hline $\mathrm{PCN}-05 \mathrm{H}$ & 71.4 & 3.07 & 26.6 & 79.0 & 4.01 & 36.0 \\
\hline $\mathrm{PCN}-06 \mathrm{H}$ & 732 & 4.57 & 30.7 & 63.4 & 6.21 & 38.0 \\
\hline
\end{tabular}

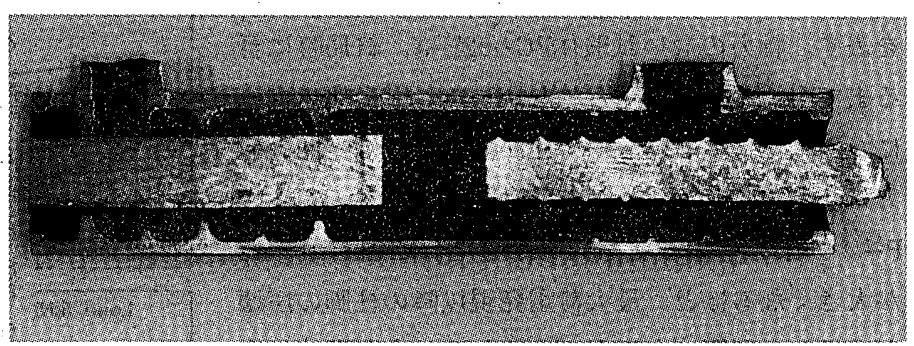

写真1 実験柊了後の維手断面
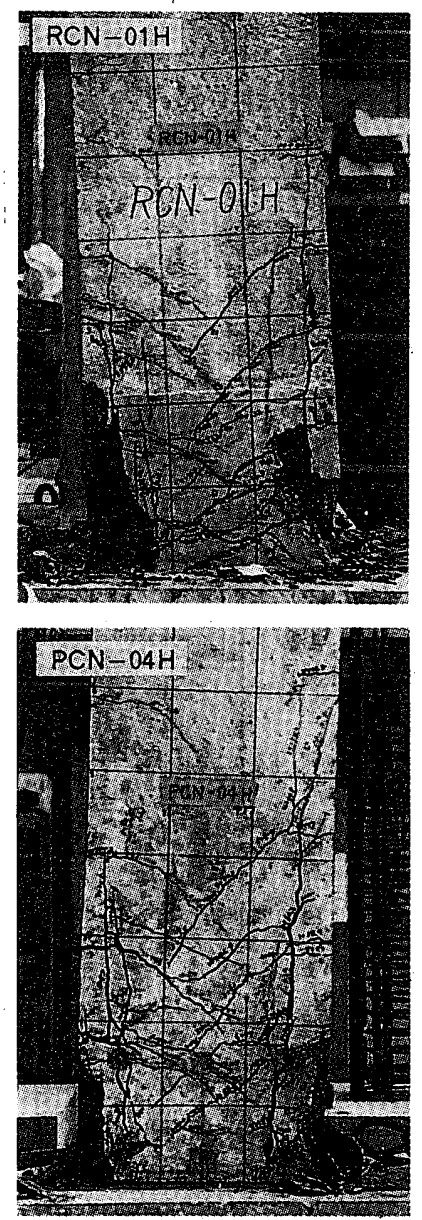
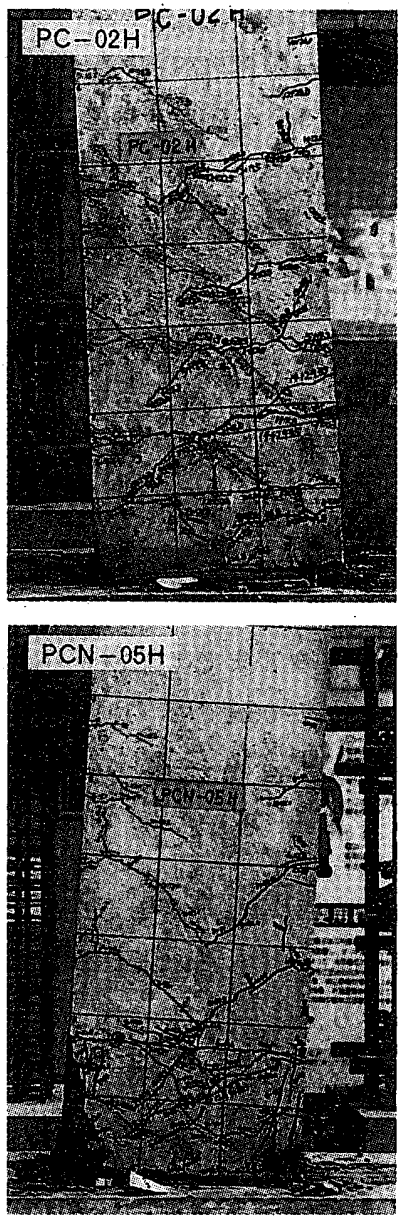

写真2 最終破垴性状
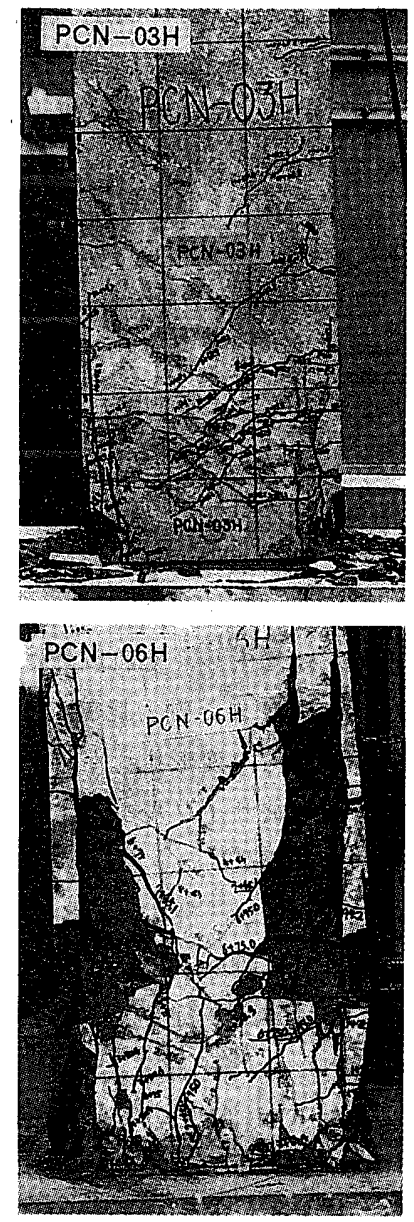
と思われる。またRC試験体はPCa試験体のような 接合界面を持たないため, すべりによるエネルギー 吸収が少ないことも一因であると考えられる。

なお，軸力のない試験体PC-02Hを除き，正側負 側の耐力に差が生じている。これは高強度コンクリ 一トの場合引張強度が無視できず，またひび割れ形 成が正負で異なるため，荷重に差が生じたものと考 えられる。特に圧縮側コンクリートに圧塿が生じて からはその差が顕著になるものと思われる。軸力の ない試験体では正負の差がほとんど見られなかった のに対し, 軸力比の高い試験体ほど正負の耐力の差 が大きくなることが認められた。

また実験によって得られた荷重一部材角履歴曲線 を図4に示す。図中のX軸に対する斜線はP $-\delta$ 効果 を表す。軸力のない試験体PC-02Hは，終局時に至 るまで耐力の低下は見られなかった。軸力比の違い について比較すると，軸力比が高くなるほど曲げ耐 力は上昇するが，最大強度到達後の耐力低下は， $\mathrm{P}-\delta$ 効果を考慮しても大きかった。これは軸力比 が大きくなるほど, 最大荷重発現以降の柱脚の圧壊 が進行した影響であると考えられる。また配筋の違 いについて比較すると、継手部かぶり厚を $30 \mathrm{~mm}$ 確 保した試験体PCN-04H, 継手部帯筋を端部に集中 させた試験体 $\mathrm{PCN}-05 \mathrm{H}$ と，標準型試験体 $\mathrm{PCN}-$ 03Hと同等の強度および勒性能を有していることが 認められた。

\section{4 試験体の妿形量}

図5に軸力比の違いによる部材角とすべり変形量 比の関係を示す。ここですべり変形量比とは, 高感 度変位計によって測定された柱脚と基礪スタブ間の 相対すべり変形量を, 加力点での全体変形量で除し たものである。軸力のない試験体PC-02Hは，最終サイクルまです ベり変形量比は增加する傾向が見られた。これに対し，軸力比0.2 の試験体 $\mathrm{PCN}-03 \mathrm{H}, 05 \mathrm{H}$ ， $10 \times 10^{-3} \mathrm{rad}$ 付近まで徐々にすべり変 形量比が増大し，それ以降は最終サイクルまでほぼ5\%と一定の値

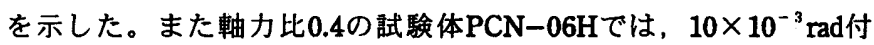
近まですべり変形量比が増加した後, $15 \times 10^{-3} \mathrm{rad}$ 付近をピークと して，最終サイクルまですべり変形量比は逆に隇少した。これは， 高強度コンクリートを用いた柱の場合，普通強度に比して高軸力と なることから，接合モルタル界面の摩擦が非常に大きくなり，それ によって柱脚のすべり変形が抑制されるためであると考えられる。 総じて軸力比が高くなるほど，すべり変形量比は低くなる傾向が認 められた。

またRCN-01H，PCN-03H試験体の，正側における，全体変形 に占める各変形要素の割合を図6に示す。このうち回転による変形 は，引張側主筋の抜け出しによる目開き量と圧縮側コンクリートの 圧壞による縮み量の和にアーム長さを除して検出し，すべり変形は
表4 諸强度一臨

\begin{tabular}{|c|c|c|c|c|c|c|}
\hline \multicolumn{2}{|l|}{ 樲験体 } & $\begin{array}{c}\text { 曲け初 } \\
\text { ひひ割れ } \\
\text { 荷重 (部材角) } \\
\mathbf{k N}\left(\times 10^{-1} \mathrm{rad}\right)\end{array}$ & $\begin{array}{c}\text { 曲げせん断 } \\
\text { ひび割れ } \\
\text { 荷重 (部材角) } \\
\mathrm{kN}\left(\times 10^{-3} \mathrm{rad}\right)\end{array}$ & 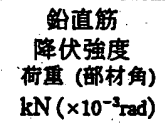 & $\begin{array}{c}\text { 最大強度 } \\
\text { 荷重 (部材角) } \\
\mathbf{k N}\left(\times 10^{-3} \mathrm{rad}\right)\end{array}$ & $\begin{array}{c}\text { 85\%酎力 } \\
\text { 低下時 } \\
\text { 僻 (部材角) } \\
\mathrm{kN}\left(\times 10^{-3} \mathrm{rad}\right)\end{array}$ \\
\hline \multirow{2}{*}{$\mathrm{RCN}-01 \mathrm{H}$} & 正 & $477 \quad(2.2)$ & $558 \quad(3.1)$ & $552 \quad(5.9)$ & $616 \quad(10.4)$ & $519 \quad(15.8)$ \\
\hline & 負 & $296(-1.1)$ & $441(-2.9)$ & - & $532(-11.4)$ & $432(-16.1)$ \\
\hline \multirow{2}{*}{$\mathrm{PC}-02 \mathrm{H}$} & 正 & $80.4(1.0)$ & $194(5.9)$ & $143(3.0)$ & $280 \quad(51.9)$ & $-\ldots$ \\
\hline & 角 & $70.6(-0.94)$ & $200(-5.0)$ & & $292(-52.0)$ & \\
\hline \multirow{2}{*}{$\mathrm{PCN}-03 \mathrm{H}$} & 正 & $416 \quad(1.4)$ & $549 \quad(4.4)$ & $573 \quad(4.9)$ & $658 \quad(8.87)$ & $557 \quad(19.6)$ \\
\hline & 負 & $245(-0.95)$ & $431(-4.4)$ & & $515(-9.31)$ & $433(-19.6)$ \\
\hline \multirow{2}{*}{$\mathrm{PCN}-04 \mathrm{H}$} & 正 & $394 \quad(1.7)$ & $530 \quad(3.6)$ & $611 \quad(6.5)$ & $651 \quad(8.78)$ & $551 \quad(17.2)$ \\
\hline & 負 & $294(-2.0)$ & $468(-4.8)$ & - & $549(-11.5)$ & $456(-18.5)$ \\
\hline \multirow{2}{*}{$\mathrm{PCN}-05 \mathrm{H}$} & 正 & $424 \quad(2.3)$ & $559 \quad(5.5)$ & $579 \quad(7.1)$ & $620 \quad(11.2)$ & $520 \quad(21.3)$ \\
\hline & 負 & $319(-2.5)$ & $441(-5.8)$ & - & $511(-11.2)$ & $426(-23.0)$ \\
\hline \multirow{2}{*}{$\mathrm{PCN}-06 \mathrm{H}$} & 正 & $692(2.8)$ & $951 \quad(15.1)$ & $936 \quad(7.5)$ & $951 \quad(9.72)$ & $857 \quad(15.3)$ \\
\hline & 負 & $438(-3.6)$ & $647(-15.1)$ & - & $648(-8.72)$ & $551(-13.9)$ \\
\hline
\end{tabular}

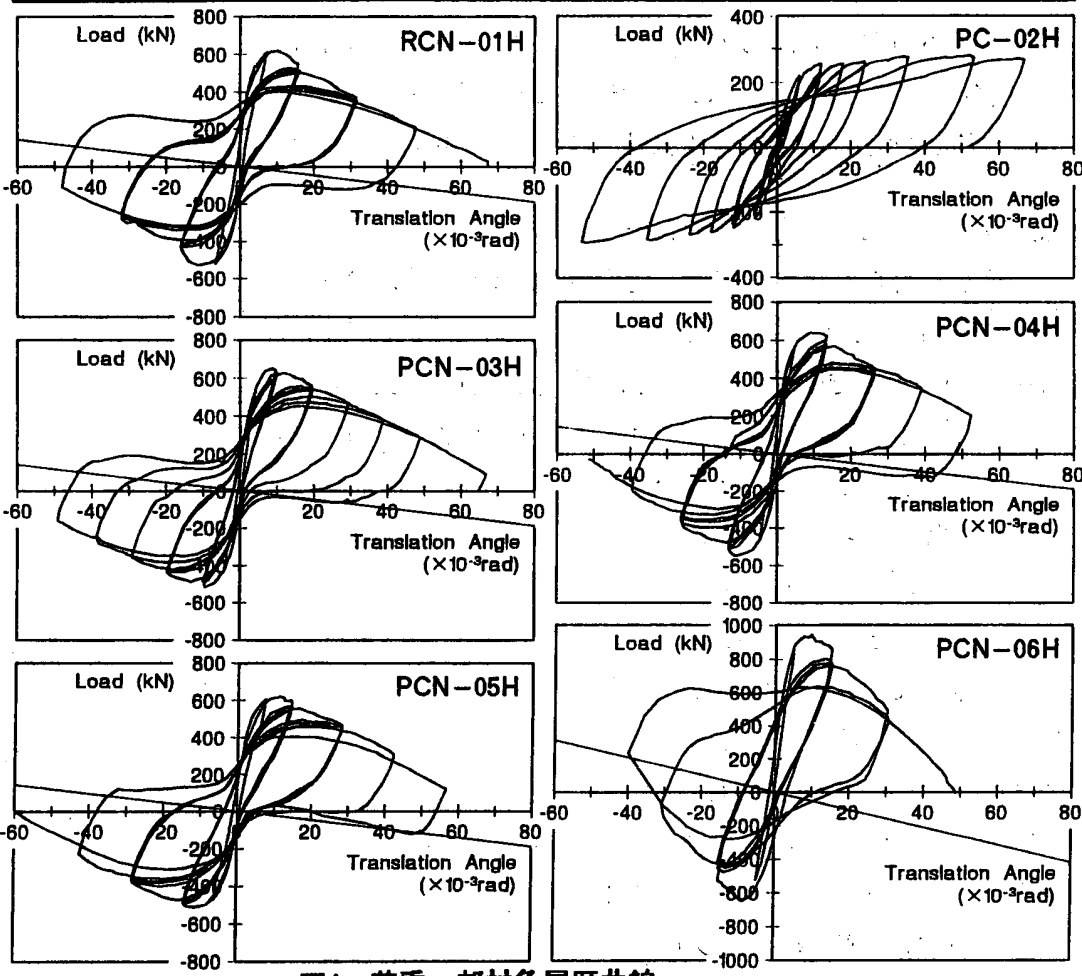

图4 荷重一部材角层歴曲線

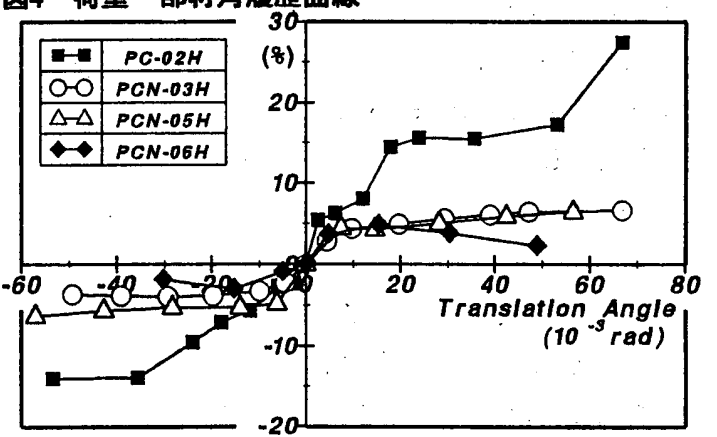

国5 部材角とすべり変形量比の関保

柱脚部と基礎スタブ間の相対すべり量より検出した。その結果, $\mathrm{PCa}$ 試験体PCN-03Hは，変形の進行に伴ってせん断変形の比が隇 少し, 逆に脚部の目開きによる回耺変形の比が增大する傾向が認め られた。一方, RC試験体RCN-01Hでは，微少変形時を除き，変形 の大半は曲げ変形比で占められ, 俆々に增加する傾向が見られた。 それに伴い，せん断変形の比，回耺変形の比ともわずかに減少する 
傾向が認められた。これは，PCa試験体においては，脚部に剛性の 高い継手が配されているために，終局時まで圧壊が進むことなく柱 部分が回転をしたためであると考えられる。一方RC試験体では， 変形の進行に伴って脚部の圧壊が進展し，また接合界面がないため 柱底面以上部の曲げひび割れが進行したことから，終局時において は全体変形の大部分が曲げによる変形で占められたものと考えられ る。すべりによる変形比は微少であった。

\section{5 等価粘性減衰定数}

試験体の復元力特性を調べるため，等価粘性減衰定数heを算出 した。部材角との関係を図7に示す。PCa慗準型試験体PCN-03Hは, RC試験体RCN-01Hに比してheの值が大きく発現した。これは柱脚 に継手を配したことにより，脚部の剛性が上昇し，圧壊が抑制され たためであると考えられる。また配筋の違いによる影響はほとんど 見られなかったが, PCN-05Hの初期 $\left(15 \times 10^{-3} \mathrm{rad}\right)$ にheの值がやや 大きかった。これは継手端部にせん断補強筋を集約させたことによ り，継手部近傍の帯筋比も若干上昇しているため，エネルギー吸収 が向上したことによるものと推測される。

\section{4. 曲げ・せん断抵抗機構}

4.1 曲げ・せん断抵抗モテル

PCa柱に圧縮軸力と曲げモーメントが作用するとき，部材内には 曲げ・せん断抵抗機構が形成される。この部材内に生じる抵抗機構 についてモデ化を行うため, 光弾性手法によって部材内に働く応 力状態を検証した。試験体形状は，3mm厚の2枚のエポキシ樹脂板 合わせ面にそれぞれ半円形の践を掘り，直径 $1 \mathrm{~mm}$ 銅線による接 合筋を引張側に，柱頭柱脚側各1本ずつ㨂入した後、透明なエポキ シ系接着䨩にて貼り合わせた。PCa部材であることから，上下スタ ブと柱間は銅線のみによって緊結され，いずれも縟は切れている。 加力は本論における曲げせん断抵抗モデルが片持加力方式に限定し ている訳ではないこと，また主応力状態を求めやすいことから，逆 対称モ一メントが生じるよう加力した。逆対称加力に際し，上下ス タブが平行に移動するよう，プレートによってスタブ間を拘束した。 1/4波長板を取り外した透過型の平行光束光弾性装置を用い, $5 \sim 10^{\circ}$ ごとに偏光板を回転させて生じた等傾線縞を振影し，重ね合わせた 等傾線図を図8(a)に示す。線に付せられた数值は偏光板の角度を示 す。さらに等傾線図より主応力方向を導き，連続する線として処理 をし，求められた主応力線図は図8(b)のように表わされる(3)。

その結果, 柱脚部の領域で発生した曲げひび割れは主応力線に治 って進展し、ひび割れ間に圧縮ストラットが形成され，曲げモーメ ントに抵抗している様子が観測された。最終破㙖性状において，継 手部かぶり厚30mmの $\mathrm{PCN}-04 \mathrm{H}$ や軸力比の大きい $\mathrm{PCN}-06 \mathrm{H}$ 試験体で, 継手頂部付近が外側に押し出されていることからも，圧縮ストラッ トが生じていることが推察される(2)。また上下の圧縮領域を結ぶ ように，アーチに対応する圧縮ストラットが形成され, 軸方向力に 対応している様子も観測された。いずれの圧縮ストラットも両端の 圧縮領域にて面積が小さく(狭く)なっているが，これは主応力線図 に対応しているためで，圧縮領域での内部応力の上昇を意味する。
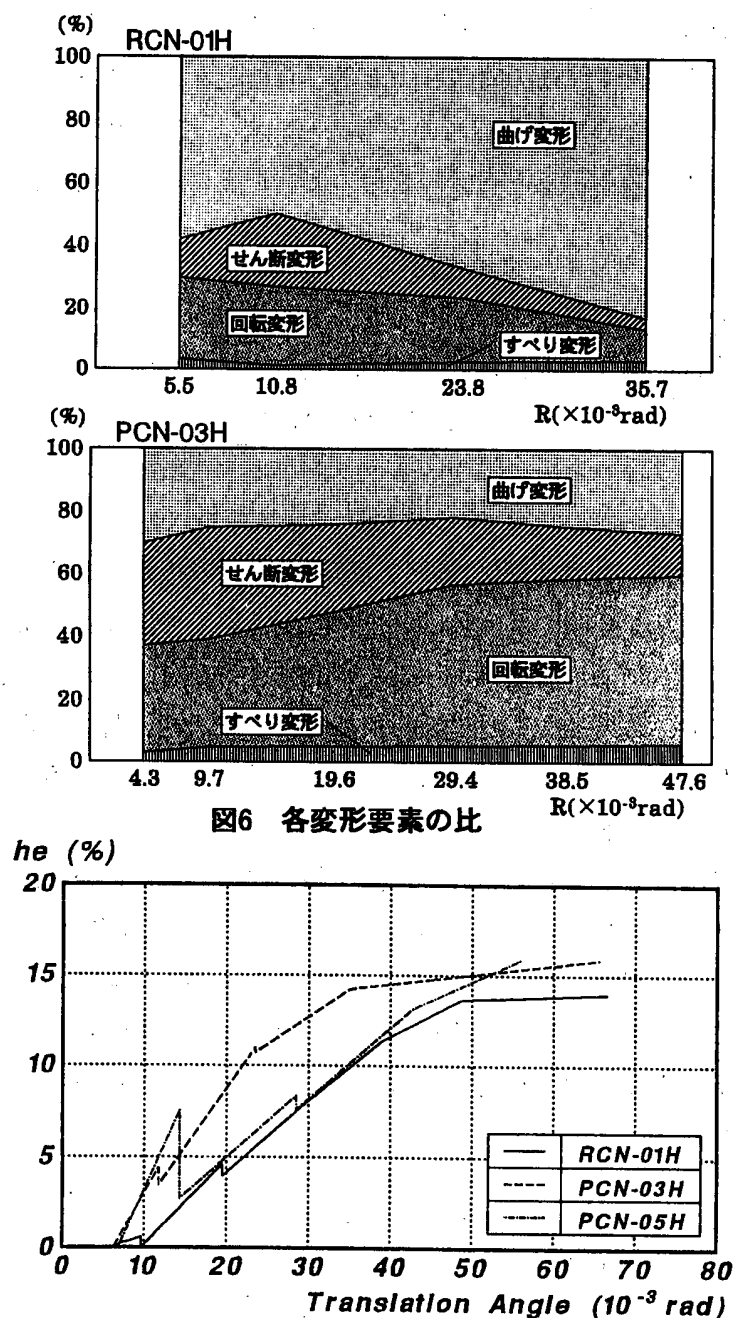

図7部材角と等価粘性減衰定数の関保

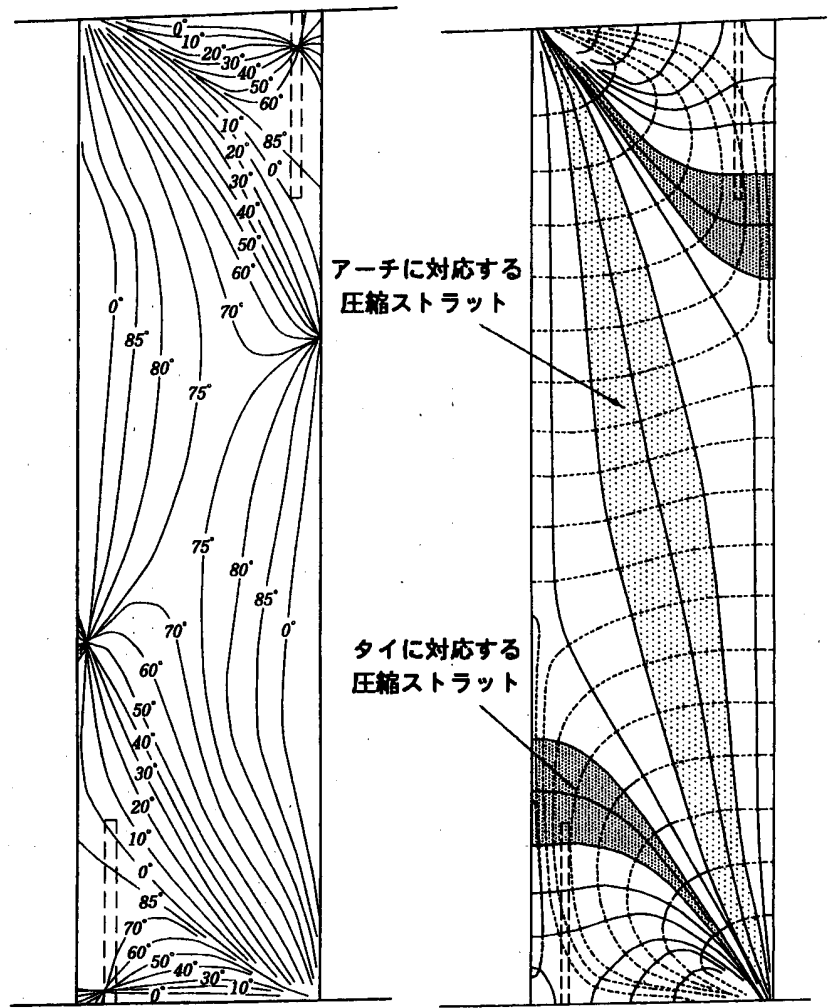

(a) 等倾線図

(b) 主応力線図

図8 光弾性実験による圧酟ストラットの形成に関する梌媓 
このように，PCa柱部材に圧縮軸力と曲げモーメントが作用すると き引引張主筋と中間筋の降伏合力と验り合った，圧縮ストラットに よる抵抗機構が形成されるものと考えられる。ここでは, 図9(a)に 示される圧縮ストラットモデルを用いて，以下に解析を行う。

\section{2 圧藮ストラットータイ作用}

部材の端部に配筋された主筋および中間筋の引張力 $\mathrm{Tt}, \mathrm{Tm}$ がそ れぞれ降伏に達すると，部材内では概ね材端から部材成Dだけ離れ た引張領域から，材端部の圧縮領域にかけて，主筋および中間筋の 引張力と釣り合いを保つ圧縮ストラットが形成されるものと考えら れる(図9(b))。通常，いわゆるせん断破震メカニズムにおけるトラ ス作用の場合, トラス筋(引張側主筋)は未降伏の状態であるためそ の影響が小さく評価の対象とはならないが，本論では曲げせん断破 鉬メカニズムにおいて主筋および中間筋(タイ)の降伏後を前提とし ている点で, 終局強度型耐震設計指針に表されるせん断設計式と大 きく異なる。このため本論では, タイと圧縮ストラットの釣り合い に関し，圧縮ストラットータイ作用と呼ぶ。

この圧縮ストラットにおいて，部材端の圧縮領域に接合し，材軸 との傾斜角 $\phi$ をもつ帯状ストラット部では，圧縮庶力度 $\sigma$ tとせん

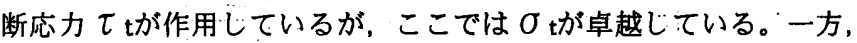
部材端の圧縮領域では, 垂直応力 $\sigma_{\mathrm{x}}, \sigma_{\mathrm{y}}$ およびせん断底力 $\tau_{\mathrm{xy}}$ の直交系の平面応力場を構成する。この両者は, 次式によって関係 ブけられる。

$$
\begin{aligned}
& \sigma_{\mathrm{x}}=\sigma_{\mathrm{t}} \sin ^{2} \phi-2 \tau_{\mathrm{t}} \sin \phi \cos \phi \\
& \sigma_{\mathrm{y}}=\sigma_{\mathrm{t}} \cos ^{2} \phi+2 \tau_{\mathrm{t}} \sin \phi \cos \phi \\
& \tau_{\mathrm{xy}}=\sigma_{\mathrm{t}} \sin \phi \cos \phi-\tau_{\mathrm{t}}\left(\cos ^{2} \phi-\sin ^{2} \phi\right)
\end{aligned}
$$

上式の第1式および第2式において， $\sigma_{\mathrm{x}=0,} \sigma_{\mathrm{y}=\beta \mathrm{t}} \sigma_{\mathrm{B}}$ とおくと， 圧縮ストラットに生じる垂直応力度 $\sigma$ tは次式で与えられる。

$$
\sigma_{\mathrm{t}}=\sigma_{\mathrm{y}=\beta_{\mathrm{t}}} \sigma_{\mathrm{B}}
$$

またせん断伝達能力をQtとおき， $\tau$ xy=Qt/kbDで表す。ここで $\mathbf{k}$

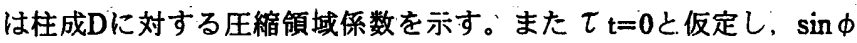
$=\frac{\tan \phi}{\sqrt{1+\tan ^{2} \phi}}, \cos \phi=\frac{1}{\sqrt{1+\tan ^{2} \phi}}$ の関係を用い, さらにタイ 作用による圧縮ストラットの傾き $\phi は$ 余り大きくないと考えられる ので $\tan ^{2} \phi \approx 0$ と仮定すれば, (1)式の第3式は次式のように表される。

$$
\tau_{\mathrm{xy}} \cdot \frac{\mathrm{Qt}}{\mathrm{kbD}}=\sigma_{\mathrm{t}} \tan \phi
$$

(2)式を(3)式に代入すると，せん断伝達能力Qtは，次式のように導 かれる。

$$
\mathbf{Q t}=\beta \mathrm{t} \cdot \mathbf{k} \cdot \mathrm{b} \cdot \mathrm{D} \cdot \sigma_{\mathrm{B}} \cdot \tan \phi
$$

いま，部材端部における主筋および中間筋の降伏引㖘力 $\mathrm{Tt}$, $\mathrm{Tm}$ と, コンクリートの圧縮合力 $\mathrm{C}$ のつり合い式: $\mathrm{Ct}=\mathrm{T} t+\sum \operatorname{Tm}$ から, 次 式が得られる。

$$
\beta \mathrm{t} \cdot \mathbf{k} \cdot \mathbf{b} \cdot \mathrm{D} \cdot \sigma_{\mathrm{B}}=\mathrm{at}_{\mathrm{t}} \sigma_{\mathrm{y}}+\dot{\gamma} \sum \mathrm{am}_{\mathrm{m}} \cdot \sigma_{\mathrm{y}}
$$

ここで， $a_{t}, a_{m}$ は，それぞれ主筋および中間筋の断面積で，中間 筋は主筋間に配筋された全ての鉄能を対象とする。ここでは高強度 コンクリートを対象としているために圧縮域におけえ鉄筋コンクリ 一トの玨維合力が大きくなり，それに比して鉄筋の压縮合力は小さ いことから圧縮鉄筋の応力は無視した。 $\sigma$ yは鉄筋の降伏点強度を， rは有効係数をそれぞれ示す。

(5)式を(4)式に代入し，図9(b)から， $\tan \phi=\xi \cdot \frac{\mathrm{D}}{\mathrm{Hs}}$ を用いると， せん断伝達能力Qtは, 次式で与えられる。

$$
Q t=\xi\left(a_{t} \cdot \sigma_{y}+\gamma \Sigma a_{m} \cdot \sigma_{y}\right) \frac{D}{H s}
$$

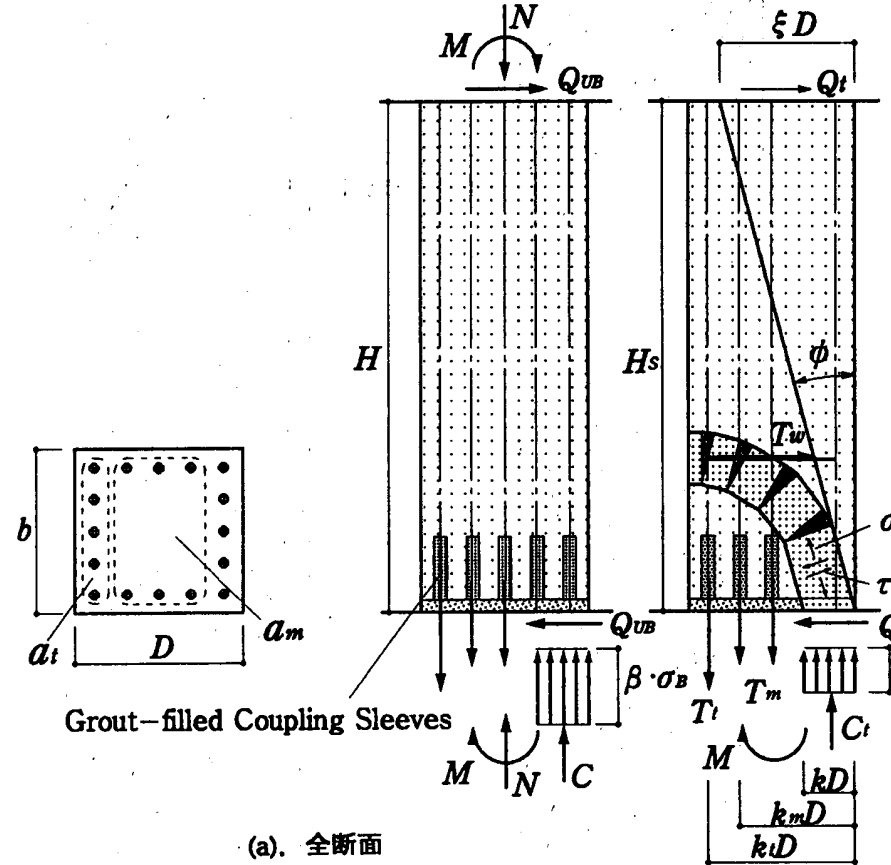

(b). 压唃ストラットータイ作用

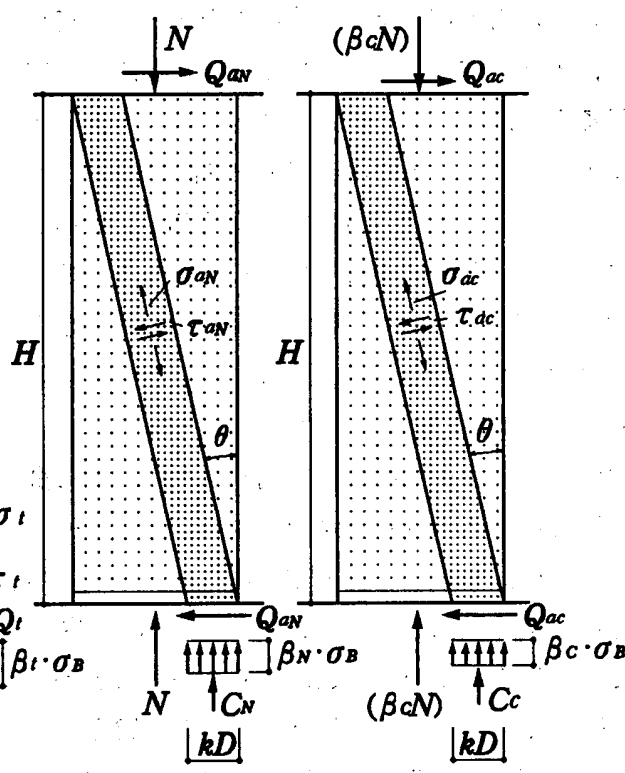

(c). 軸カによるアーチ作用

に上るアーチ作用 
ここでHsは柱全長Hの1/2に相当するシアスパン長で，Hs/Dはシア スパン比をそれぞれ示す。また $\xi$ は見掛け上の摩擦係数を意味する。

\section{3 アーチ作用}

軸方向力Nとせん断力QaNを受けた部材には，図9(c)に示すように， 部材端の圧縮領域に向かって，材軸と $\theta$ の傾斜角をもつ帯状の圧縮 ストラットが形成される。この圧縮ストラットには, 垂直応力度 $\sigma$ aNとせん断応力度 $\tau$ aNが作用する。また圧縮ストラットが接合 する部材端の圧縮領域では, 垂直応力度 $\sigma_{\mathrm{x}}, \sigma_{\mathrm{y}}$ およびせん断応力 度 $\tau$ xyの応力場を構成している。この両者の間には, 夕イ作用の 場合と同じ関係が成り立つので，(1)式を用い， $\sigma_{x=0,} \sigma_{y=\frac{N}{k b D}}$ の関倸から次式が成り立つ。

$$
\frac{\mathrm{N}}{\mathrm{kbD}}=\sigma \mathrm{aN}
$$

また(1)式より，圧縮ストラットによるせん断伝達能力をQaNとおき， $\tau_{\mathrm{xy}}=\mathrm{QaN} / \mathrm{kbD}$ ，および $\tau$ aN $=0$ とおくと，次のように導かれる。

$$
\frac{\mathrm{QaN}}{\mathrm{kbD}}=\sigma \mathrm{aN} \tan \theta
$$

上式に，図9(c)から求めた $\tan \theta=\mathrm{D}(1-\mathrm{k}) / \mathrm{H}$ と(7)式を代入し，パラ

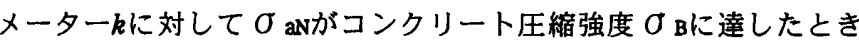
の上限值を適用すると，せん断伝達能力QaNは次式で与えられる。

$$
\mathrm{QaN}=\frac{\mathrm{D}}{\mathrm{H}}(1-\eta) \mathrm{N}
$$

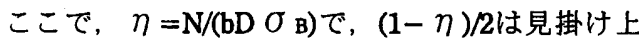
の摩摖係数を示す。

次に高強度コンクリートの場合, 圧縮強度に対 して圧縮余裕度が生じるため；部材内には図9(d) に示すように，このコンクリート圧縮力による等 価軸方向力 $\beta \mathrm{c} \cdot \mathrm{N}$ に相当する付加的な圧縮ストラ ットが形成される。この任縮ストラットには，垂 直応力度 $\sigma$ acとせん断応力度 $\tau$ acが作用するが, これらの応力度と部材端部の圧縮領域における応 力場 $\sigma \mathrm{x}, \sigma_{\mathrm{y}}, \tau_{\mathrm{xy}}$ との間の関係は, (1)式と同じ 形で書き表される。ここで $\sigma_{\mathrm{x}}=0, \sigma_{\mathrm{y}}=\sigma_{\mathrm{ac}}=$ $\beta_{\mathrm{c}} \sigma_{\mathrm{B}}, \tau_{\mathrm{xy}}=\mathrm{Qac} / \mathrm{kbD}$ とおき,$\quad \eta=\mathrm{N} / \mathrm{bD} \sigma$ вの 前述の結果を用いると，せん断伝達能力Qacは次 式のように導かれる。

$$
\mathrm{Qac}=\frac{\mathrm{D}}{\mathrm{H}} \beta_{\mathrm{c}}(1-\eta) \mathrm{N}
$$

これより，アーチ作用によるせん断伝達能力 Qaは，(9)および(10)式の累加式として，次のよう に与えられる。

$$
\mathrm{Q}_{\mathbf{a}}=\frac{\mathrm{D}}{\mathrm{H}}(1+\beta \mathrm{c})(1-\eta) \mathrm{N}
$$

\begin{tabular}{|c|c|c|c|c|c|c|}
\hline \multirow{3}{*}{ 試穓体名 } & \multirow{3}{*}{$\begin{array}{c}\text { 実瞼值 } \\
\text { 最大強度 } \\
\text { eQu (kN) }\end{array}$} & \multicolumn{4}{|c|}{ 算定僆 } & \multirow{3}{*}{$\begin{array}{c}\text { 実㛟值／ } \\
\text { 算定倠 }\end{array}$} \\
\hline & & \multicolumn{2}{|c|}{ タイ作用 cQut } & \multirow{2}{*}{$\begin{array}{c}\text { アー千 } \\
\text { 作用 } \\
\mathrm{cQua}(\mathrm{kN})\end{array}$} & \multirow{2}{*}{$\begin{array}{c}\text { 即 } \\
\mathrm{cQu}(\mathrm{kN})\end{array}$} & \\
\hline & & $\begin{array}{l}\text { 主筋 } \\
(\mathrm{kNN})\end{array}$ & $\begin{array}{c}\text { 中間筋 } \\
(\mathrm{kN})\end{array}$ & & & \\
\hline $\mathrm{RCN}-01 \mathrm{H}$ & 616 & 166.4 & 41.6 & 413.9 & 622 & 0.99 \\
\hline $\mathrm{PC}-02 \mathrm{H}$ & 292 & 166.4 & 41.6 & 0 & 208 & 1.40 \\
\hline PCN-03H & 658 & 166.4 & 41.6 & 415.6 & 624 & 1.05 \\
\hline $\mathrm{PCN}-04 \mathrm{H}$ & 651 & 166.4 & 41.6 & 413.1 & 621 & 1.05 \\
\hline $\mathrm{PCN}-05 \mathrm{H}$ & 620 & 166.4 & 41.6 & 410.0 & 618 & 1.00 \\
\hline$\overline{\mathrm{PCN}}-06 \mathrm{H}$ & 951 & 166.4 & 41.6 & 661.6 & 870 & 1.09 \\
\hline
\end{tabular}

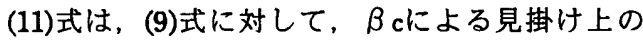
摩擦力が増加したことを示している。

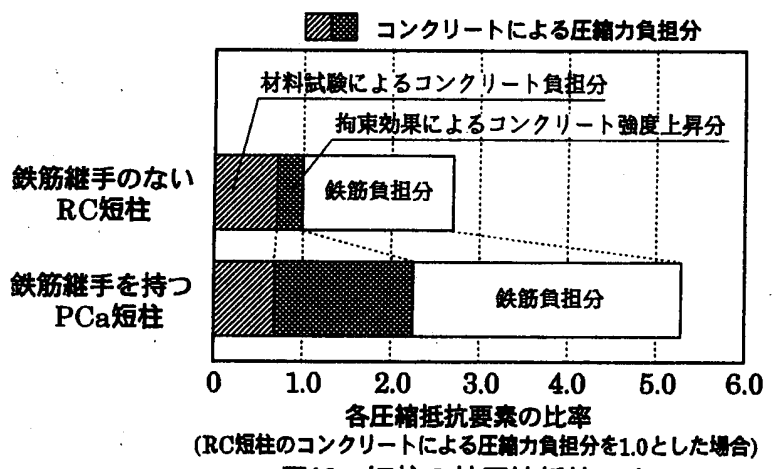

図10 短柱の軸压樎抵抗要素

多イ作用

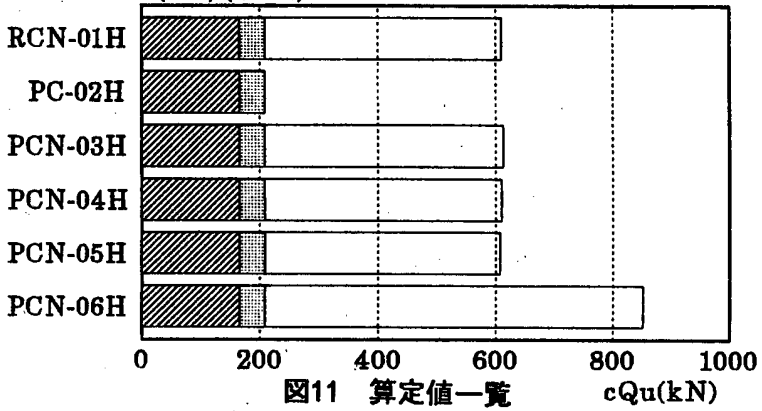

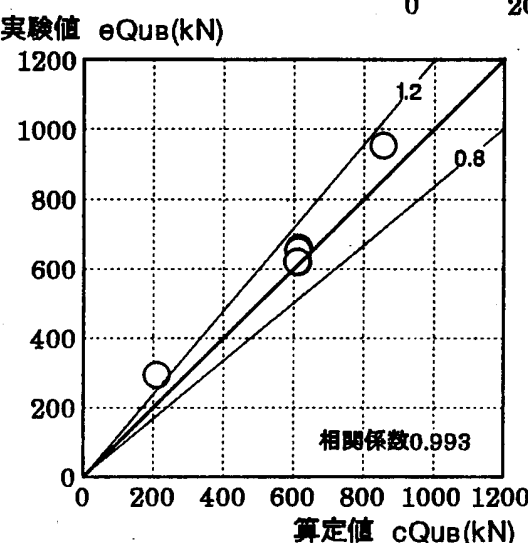

図12 実験值と算定值の比較

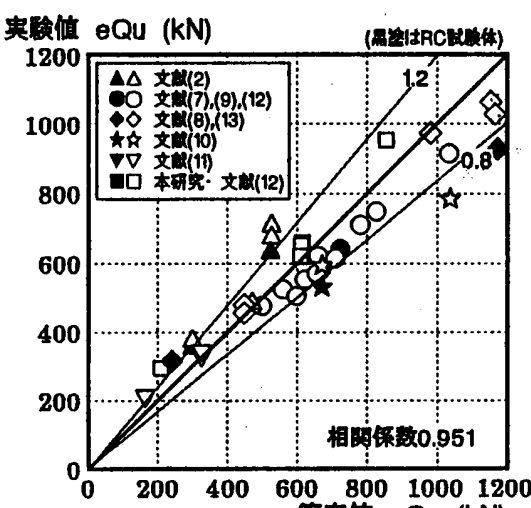

(a) 本諭提案式 宣定值 $\mathrm{CQU}(\mathrm{kN})$

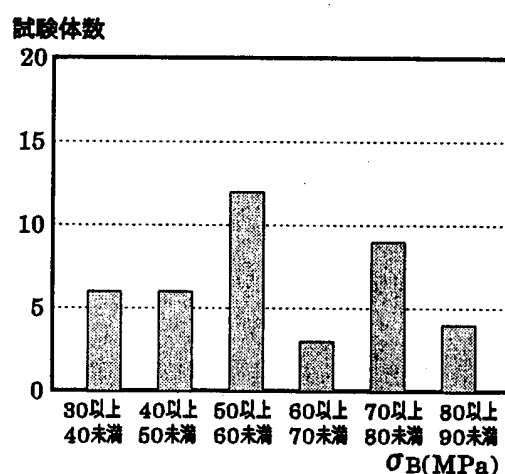

図13 コンクリート圧樎強度の分布

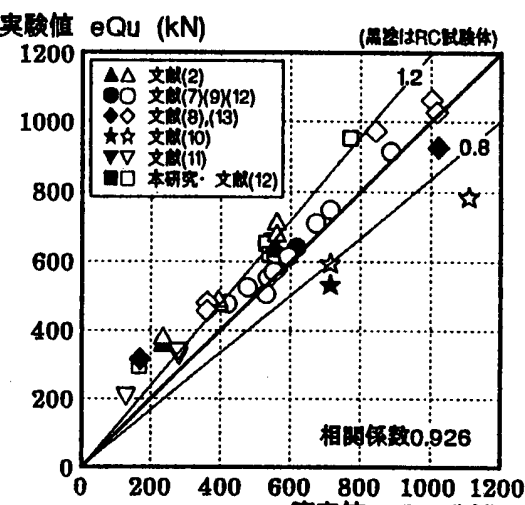

(b) 多段尼筋式 宣定值 cQu (kN)
図14 実験値と算定值の比較 


\section{4 諸係数の仮定}

圧縮ストラットによる，"タイ作用およびアーチ作用から導かれた せ九断伝達能力評価式に含まれるパラメーター 以下のように仮定される。パラメーターもは，接合界面における

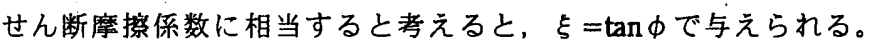
ここで，内部摩擦角 $\phi$ は，コンクリートの打継ぎ部に対する Johansenの実験 ${ }^{(4)}$ から，37 の值を採用する。これより， $\xi=0.75$ が得られる。

パラメーター $\gamma$ は, 主筋の引張力に対する中間鉄筋の引張力の比, いわゆる中間鉄筋の効果係数を意味する。この効果係数は，中間鉄 筋が全て降伏点に達し ${ }^{(5)}$ ，圧縮合力から鉄筋までの距離に比例す ると仮定すると，主筋までの距離に対する中間鉄筋までの距離の比 を計算すると, その比の平均値はおおむね $0.5 に$ 等しくなる。

パラメーター $\beta$ cは，圧縮ストラットータイ作用において，コン クリートの引張抵抗を無視しているために，アーチ作用によってコ ンクリートの有効部分が增加したと考えれば，コンクリートの圧縮 強度のおよそ $1 / 10$ に相当するとの仮定が得られる。既往の研究から 高強度コンクリートを用いた部材実験の引張強度は, 圧縮強度の約

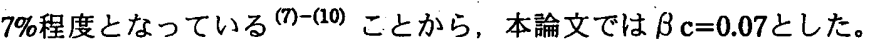

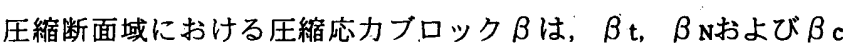
の総和で与えられるが，これらの係数の総和はおおむね2.0に等し くなる。これは，せん断伝達能力における圧縮強度が，コンクリー トシリンダーの一軸圧縮強度の2倍にも達することを示す。グラウ ト充填式スリーブ継手を有する短柱の圧縮試験によると, 図10に示 すように横補強筋の拘束効果によって，コアコシクリートの圧縮強 度は，コンクリートシリンダーの一軸圧縮強度の 2 倍以上になるこ とが確認された ${ }^{(\theta)}$ 。これより, 圧縮応力に対して仮定した值は, 実状に即しているものと考えられる。

\section{5 全せん断伝達能力}

以上，得られたタイ作用およびアーチ作用によるせん断伝達能力 を累加した值が，曲げせん断部材降伏時の全せん断伝達能力となる。 したがって，(6)式と(11)式から，次式が与えられる。

$$
\begin{array}{r}
\mathrm{QuB}=\frac{\mathrm{D}}{\mathrm{Hs}}\left\{\xi\left(\operatorname{at}_{\mathrm{t}} \sigma_{\mathrm{y}}+\gamma \sum \mathrm{am}_{\mathrm{m}} \sigma_{\mathrm{y}}\right)\right. \\
\left.+\frac{1}{2}(1+\beta \mathrm{c})(1-\eta) \mathrm{N}\right\}
\end{array}
$$

また，上式は次のように無次元化した形でも 表現することができる。

$$
\begin{aligned}
\tau_{\mathrm{uB}} & =\frac{\mathrm{D}}{\mathrm{H}_{\mathrm{s}}}\left\{\xi\left(\mathrm{q}_{\mathrm{t}}+\gamma \sum \mathrm{q}_{\mathrm{m}}\right)\right. \\
& \left.+\frac{1}{2}(1+\beta \mathrm{c}) \eta(1-\eta)\right\}
\end{aligned}
$$

ここで, $\quad \tau_{\mathrm{uB}=\mathrm{QuB} / \mathrm{bD}} \sigma_{\mathrm{B}}, \quad \eta=\mathrm{N} / \mathrm{bD} \sigma_{\mathrm{B}}$, $\mathrm{q} \mathrm{t}=\mathrm{a}_{\mathrm{t}} \sigma_{\mathrm{y} / \mathrm{bD}} \sigma_{\mathrm{B}}, \mathrm{q}_{\mathrm{m}=\mathrm{am}} \sigma_{\mathrm{y} / \mathrm{bD}} \sigma_{\mathrm{B}}$ である。

(14)式において， $\tau$ uвは $\eta=0.5$ のとき最 大值をとり，次式で与えられる。

$$
\max ^{*} \tau \mathrm{uB}=\frac{\mathrm{D}}{\mathrm{Hs}}\left\{\xi\left(\mathrm{q}_{\mathrm{t}}+\gamma \sum \mathrm{q}_{\mathrm{m}}\right)+0.125(1+\beta \mathrm{c})\right\}
$$

軸力比の最大値は，次式で与えられる。

$$
\eta_{\max }=1+\left(2 \mathrm{q}_{\mathrm{t}}+\sum \mathrm{q}_{\mathrm{m}}\right)
$$

したがって，0.5< $\eta \leqq \eta \max$ に対しては， $\tau$ uBを1次式で与えるど; 次のように書き表される。

$$
\tau \text { uB }=\frac{\eta_{\max }-\eta}{\eta_{\max }-0.5} \times \text { max } \tau \text { us }
$$

軸方向力が引張力の場合， $\eta$ の最小值は次式で与えられる。

$$
\eta \min =2 \mathrm{q}_{\mathrm{t}}+\sum \mathrm{q}_{\mathrm{m}}
$$

これより, $0<\eta \leqq \eta \min$ における $\tau_{u B}$ は次式のように得られる。

$$
\tau_{\mathrm{uB}}^{*}=\frac{\mathrm{D}}{\mathrm{Hs}_{\mathrm{s}}}\left(\mathrm{q}_{\mathrm{t}}+\gamma \sum \mathrm{q}_{\mathrm{m}}\right)\left(1-\frac{\eta}{\eta \min }\right)
$$

\section{6 訐価式の実験結果に対する適応性の検証}

(12)式によって得られた算定結果の内訳を表-5ならびに図11に示 す。本評価式はコンクリート強度が高強度の場合圧簿力に余裕度が 生じ，曲け耐力に寄与するとの観点から，この軸力に相当するコン クリート強度の増分が, アーチ効果による評価に付加される点で, 既往の耐力評価式とは異なるのが特徵である。算定値は，圧縮ス卜 ラットータイ作用負担分とアーチ作用負担分の累加によって示され, タイ作用負担分は，さらに引張側主筋と中間筋負担分に分離できる。 その結果, 軸力比 0.2 試験体の圧縮ストラットータイ作用負担分 は約35\%で，アーチ作用負担分は約65\%だった。軸力比0.4の試験体 ではタイ作用負担分は約25\%で，ア一チ作用負担分は約75\%だった。 軸力比の増大に伴って，アーチ作用負担分が上昇すえ結果になって いる。压縮ストラットータイ作用負担分のうち，中闑鉄筋の負担分 は約20\%であった。

また本実験における算定值と実験値の比較を図-12に示す。実験 值に対する算定值の比は，軸力のある試験体では0.99〜 1.09に分布 しており，適切に評価されていることがわかる。軸力のない試験体 は過小評価の傾向が見られた。相閤係数は0.99であった。

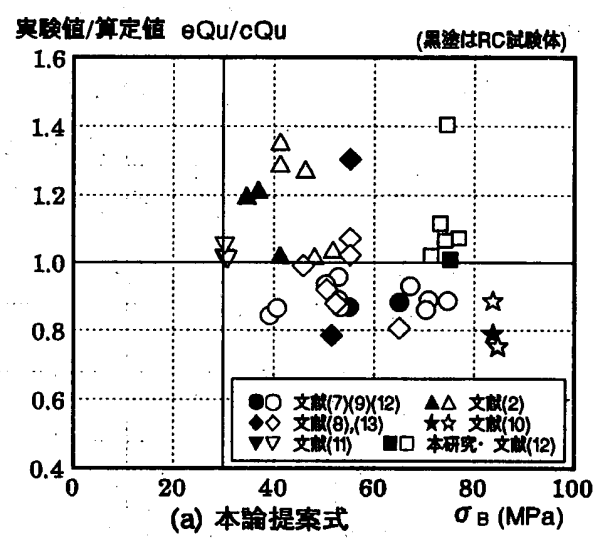

図15 (a) 本敂提案式

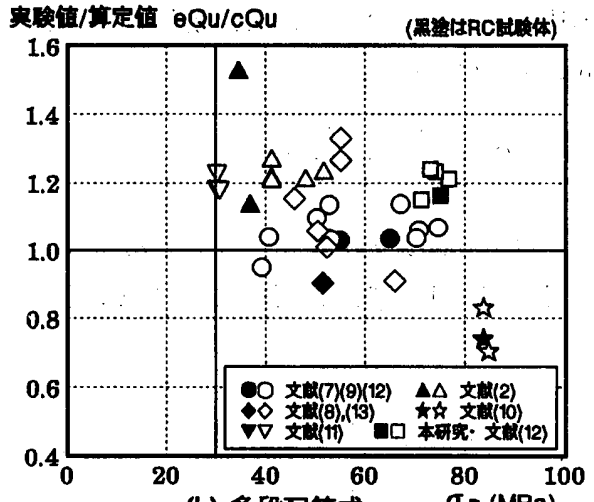

(b) 多段西筋式

$\sigma_{\mathrm{B}}(\mathrm{MPa})$

\section{実験值/算定值と $\sigma_{\mathrm{B}}$ の閶保}


同様に，継手を持つ高強度PCa柱に関する既往の実験結果につい ても検証した ${ }^{(2 h(7)-(13)}$ 。ここでは実験時のコンクリート強度が $30(\mathrm{MPa})$ 以上を高強度コンクリートと定義し, 検討の対象とした。 サンプリングした供試体のコンクリート圧縮強度の分布を図ー13に 示す。これらの強度は30～90(MPa)に分布し，圧縮強度の平均は $57.0(\mathrm{MPa})$ であった。(12)式による算定值と実験值の関係を図14(a) に，此較のため曲げ終局強度の多段配筋式(New $\mathrm{RC}$ 式) ${ }^{(14)}$ による 算定值之実験値の関係を図14(b)にそれぞれ示す。図中，白抜きの 記号はPCa試験体を, 黒塗りの記号はRC試験体を示す。曲げ耐力 の算定式としては，このほかに日本建築学会の曲け終局強度算定式 (15)があるが，中間筋を考慮せず過小評価となるためここでは比較 の対象外とした。

その結果，両式ともほとんどの試験体が $\pm 20 \%$ 以内に存在してお り，実験值を良好に評価できることが認められた。両式とも，実験 值に対する算定値の比が 0.8 を回った供試体は， RC試験体( か，破壊モードがやや異なる曲げせん断破塭型の試験体(印印)であ った。相関係数については，New RC(多段配筋)式が0.926であるの に対し，本提案式は0.951と若干高くなった。また本提案式は，曲 け耐力が低く発現した供試体から高い供試体まで比較的均等に分布 したのに対し，New RC式では曲げ耐力が低く発現した供試体はや や過小に評価され，高く発現した供試体はやや過大に評価される傾 向が喼められた。

そこで両式の実験值/算定值の比とコンクリート強度との関倸を 表したものが図15である。(a)は本提案式，(b)はNew RC式となって いる。その結果, 本提案式は実験值/算定值の比がほほ0 $0.8 \sim 1.2$ 間 に分散しているのに比べ，New RC式はほとんどの試験体が1.0以上 に分布し，下限式であるとの傾向が確認された。しかしNew RC式 は供試体ごとのばらつきが大きくなり、コンクリート強度の低い試 験体では過小に，コンクリート強度の高い試験体では過大にそれぞ れ評価される傾向が認められ，図中においてやや左上から右下に分 布している様子が見られた。よって，本論文における曲げ強度評価 式は，高強度鉄筋および高強度コンクリートを用いたPCa柱の曲げ 終局耐力を評価する上で有効であるとの見識を得た。

\section{5. まとめ}

高強度鉄筋用グラウト充填式铁筋継手を脚部に持つPCa柱の曲げ 破壊実験を行い，曲け終局耐力について比較検討した結果，以下の 知見を得た。

(1). PCa標準型の試験体 PCN-03Hは，RC試験体RCN-01Hに比し て約7\%の耐力の上昇が認められ，RC試験体と同等以上の構造性能 を有することが認められた。

(2). 軸力比の上昇に伴い最大耐力は上昇するが, 最大荷重到達以 降の耐力低下も大きかった。

(3). 継手部かぶり厚を30mm確保した試験体 $\mathrm{PCN}-04 \mathrm{H}$, 継手端部 に帯筋を集中させた試験体 PCN-05Hとも，PCa祭準型試験体 $\mathrm{PCN}-03 \mathrm{H}$ と同等の構造性能を有することが認められた。

(4).コンクリート強度が高強度の場合、コンクリート強度上昇分 が曲け終局強度に寄与するとの観点から，圧縮ストラットによるモ
テル化を行い，実験結果と比較した。その結果，いずれの試験体も 適切に評価できることが認められた。軸力比0.2の試験体では圧䈹 ストラットータイ作用負担分が約 $1 / 3$ 占め，そのうち中間筋負担 分は約 $20 \%$ 程度であった。また軸力比が上昇すると算定值のアーチ 作用負担分は增大し，実験結果と良く適合した。

(5). 本論文における提案式の汎用性について，高強度材料を用い た同様の実験結果からその適合性について検証し，既往の曲け強度 式と適応性について比較した。その結果, 本提案式流継手を持つ高 強度PCa柱についての同梯の実験結果に対し，曲け終局耐力を良好 に評価できることが認められた。また既往の多段配筋式(New RC式) とその適応性について比較した結果，New RC式はコンクリート強 度が比較的低いまたは高い試験体でやや評価にばらつきが認められ たのに対し，本提案式は少なくともコンクリート強度30～90(MPa) の範囲においては実験結果に良く对応し, 高強度PCa柱の曲げ終局 耐力評価に有効であることが認められた。

\section{【参考文献】}

(1). 林芳尚，鈴木計夫ほか：グラウト充填式鉄筋継手に関する研究の動向， コンクリート工学, Vol.34, No.4, pp.15-23, 1996.4

(2). 稘谷栄次, 王斺ほか: 高強度鉄筋用機械式継手を有するPCa部材の力学

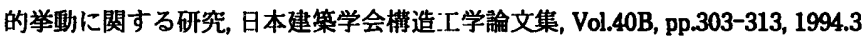
(3). 高桥賞, 澤芳炤ほか共藷 : フォトメカニクスー光学的手法による応カひ ずみならびに変形の解析，山海堂, 1996.8

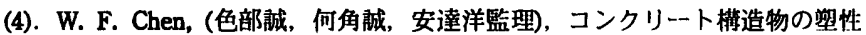
解析, 丸善, 1985

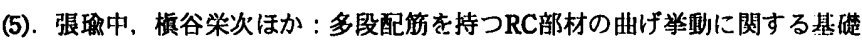

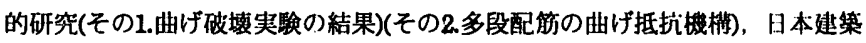

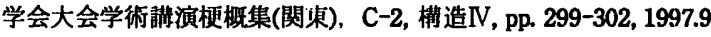

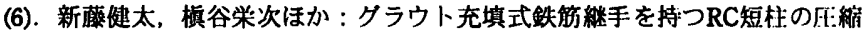
抵抗に関する研究, 日本建筮学会大会学術䄇演梗概集, C-2, 榑造IV, pp. 307$308,1998.9$

(7). 塩川真, 笠松照親ほか : 超高層RCプレキャスト工法の開発(その3.柱部材

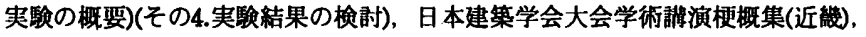

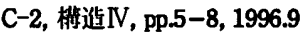

(8). 笺井文隆，小林克巳ほか：高強度鉄笳に用いるモルタル充填式継于の実 用化に関する研究(その2.PCa柱部材の変形性能に関する研究), 日本建築学会 大会学術詶演梗概集(関東), C-2, 棰造 $\mathrm{V}, \mathrm{pp} .143-144,1997.9$ (9). 金川基, 笠松照親ほか：中高層RCプレキャスト工法の開発(柱部材実䮦),

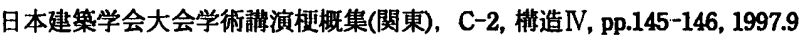
(10). 内田健一朗ほか：高強度プレキャストコンクリート柱に関する実験的研 究(その1.実馱概要およひ破填性状)(その2. 耐力および変形性状), 日本建策学会 大会学術講演梗概集(近畿), C-2, 構造 N, pp. 9-12, 1996.9

(11). 小澤健一, 槙谷栄次ほか：モルタル充填式スリーブ継乎を用いたPCa部 材の耐震性能に関する研究, コンクリート1..学年次論文報告伴, Vol.16, No.2, pp.301-306, 1994.6

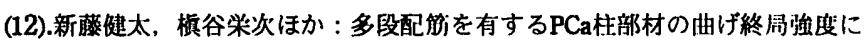

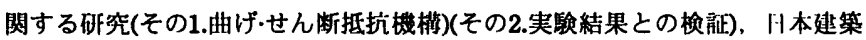

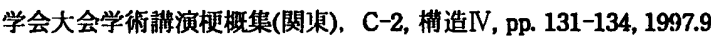

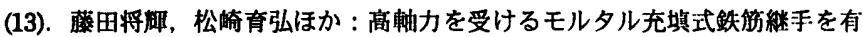
したプレキャスト柱材の糊造特性に関小る実験研究, コンクリートI学年次 論文報告集, Vol.20, No.2, pp.601-606, 1998.7

(14). 建策物の構造規定一建築基準法施行令第3章の解説と䢙用, 日本建榮セ ンター, 1997.12

（15）. 鉄笳コンクリート構造計算規準・同解説，日本建策学会，1995

(本報告の一部は、日本建策学会1997年度大会(関東)にて発表した)

(1998年 3 月 16 日原稿受理, 1998 年 9 月 29 日探用決定) 